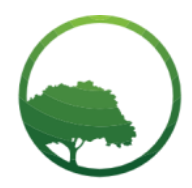

Research in Business \& Social Science

\title{
Employees' workplace well-being and work engagement of divine word colleges' employees in Ilocos region, Philippines
}

\author{
Damianus Abun@a, Theogenia Magallanesb, Grace Sylvia Lalaine Forondac, Mary Joy \\ Encarnaciond \\ a. Divine Word College of Vigan and St. Benedict College of Northern Luzon, Philippines \\ ${ }_{b}$ St. Benedict College of Northern Luzon, Philippines

c,dDivine Word College of Laoag, Philippines

\author{
A R T I CLE INFO \\ Article history: \\ Received 08 January 20 \\ Received in revised form 02 Feb 20 \\ Accepted 12 March 20 \\ Keywords: \\ Workplace well-being, Work \\ Engagement, Work satisfaction, \\ Organizational respect, Work \\ intrusion \\ JEL Classification: \\ 130, J50, J80
}

\begin{abstract}
A B S T R A C T
The purpose of the study was to determine the correlation between workplace well-being and work engagement of Divine Word Colleges' employees in the Ilocos Region. In order to support the study, theories were presented and related literature and studies were reviewed. The study used a descriptive correlational research design. The respondents of the study were all employees of the Colleges. In carrying out the study, validated questionnaires were used and in tabulating and interpreting the data, weighted mean and Pearson $r$ were used. The study found that there is a correlation between workplace well-being and work engagement of employees of Divine Word Colleges in Region I, Philippines.
\end{abstract}

(C) 2020 by the authors. Licensee BSC International Publishing, Istanbul, Turkey. This article is an open access article distributed under the terms and conditions of the Creative Commons Attribution (CC BY) license (http://creativecommons.org/licenses/by/4.0/).

\section{Introduction}

It has been a common concern of all managers on how to improve job performance, productivity, and quality. Increasing salaries and benefits may not be the single solution to achieve such purpose but it has to be comprehensive. Providing material needs such as salary and benefits may not be enough if other aspects of the human being are not given attention such as wellbeing. Wellbeing is the experience of good health which includes mind and body, happiness, prosperity, job satisfaction, sense of meaning (Davis, 2019). Such experiences are needed in order to improve the optimal functioning of every human being and they are also needed in the workplace in order to increase the performance of employees. In relation to workplace well-being, Black Dog Institute (n.d) contends that well-being is the experience of work satisfaction, respect, care and no intrusion into individual life. In addition, to create workplace well-being is providing room for autonomy, relatedness needs and competence needs (Deci \& Ryan, 2000). When employees experience job satisfaction, respect from the employer, care from the employer and no intrusion of work into private life, employees experience well-being. Deci and Ryan (2000) added further that it is also important to provide a work environment conducive for the growth of autonomy, relatedness and competence needs. These are innate psychological needs that have to be developed in order to improve human functioning.

Problems of well-being are a problem of all industries including the schools. Employees' performance is a prerequisite for organizational performance. Performance is not just the product of skills but a product of motivation and motivation occurs when the employees are taken care of. Therefore, tracking the condition of well-being and taking corrective measures to improve well-being

* Corresponding author. ORCID ID: 0000-0002-9693-1541

(C) 2020 by the authors. Hosting by SSBFNET. Peer review under responsibility of Center for Strategic Studies in Business and Finance.

https://doi.org/10.20525/ijrbs.v9i2.623 
is one of the main concerns of management. Because neglecting the workplace well-being will affect job performance, productivity, and quality as a whole. Thus, it is along with this concern that the researcher conducts the study. Concern for well-being is not limited to profit industries but it also applies to non-profit industries such as schools.

Previous studies have focused on measuring workplace well-being and work performance in different companies but the current study is trying to establish the relationship between workplace well-being and work engagement in the school setting. The author is trying to investigate the workplace well-being of employees and find out if it affects the work engagement of teachers and employees of Divine Word Colleges in the Ilocos Region.

The study is divided into five parts. The first part is an introduction that discusses the background of research and the objective of the study. The second part discusses the theory of the study and its related literature, conceptual framework, statement of the problems and hypothesis, scope and delimitation of the study. The third part is about the research methodology which discusses research design, the locale of the study, population, data gathering instrument, data gathering procedures and statistical treatment of data. The fourth part contains the result and discussion of the proposed problems of the study and lastly fifth part contains the conclusion and recommendation of the study

\section{Literature Review}

\section{Workplace Well-Being}

There has been growing attention in investigating the cause of job performance, job engagement, and job satisfaction. In order to increase job performance, managers have been searching for ways how to increase job satisfaction and work engagement. Thus, it is necessary for managers to identify the elements or variables that contribute to job performance. Along this line, it has been identified that one of the elements that promote job performance is workplace well-being. Well-being encompasses factors that affect the lives of employees in their workplace. Those factors may include their job satisfaction, their relationship with peers and management, employer care, employee autonomy, competence, and relatedness. Black Dog Institute (n,.d) particularly identifies several variables that are considered to be the elements of workplace well-being and these are work satisfaction, organizational respect for the employee, employer care and intrusion of work into private life. The variables were identified after it has conducted a study on workplace well- being and the variables were based on self-reported areas of workplace well-being identified by the employees themselves. Like Black Dog Institute's variables, Self-Determination Theory (SDT) of Deci and Ryan (2000) has presented several validated variables that contribute to workplace well- being of employees such as autonomy (deCharms, 1968), relatedness (Baumeister, \& Leary, 1995) and competence (Harter, 1978). These are three basic psychological needs and these needs are innate in nature. These three needs are called intrinsic motivational needs and they are important in improving the workplace well-being of employees. Deci and Ryan (2000) argued that the workplace environment must be supportive of the growth of these needs in order to create a healthy workplace environment and the well-being of employees.

In order to guide our direction in this paper, we need to elaborate further different variables that are identified by Black Dog Institute and Self-Determination Theory (SDT) of Ryan and Deci (2000) which are considered to contribute to the workplace well-being and these are job satisfaction, organizational respect for employees, employer care, intrusion of work into private life, autonomy, competence, and relatedness.

\section{Understanding work motivation and job satisfaction}

Motivation is a process by which activities are originated and pursued to meet certain unfulfilled needs, whether it is physical or psychological needs. It means that people pursue a certain activity or work for a reason, not just for nothing. Usually, it is always originated from the unfulfilled needs of the person. People have different needs and these needs must be fulfilled and satisfied. They direct the extent of the behavior of the person to pursue them. Related to the theory of needs, Maslow (1943) had explained the content theory of motivation. Maslow argued that humans have five needs to be fulfilled and they are physiological needs, safety needs, social needs, esteem needs, and self-actualization. Physiological, safety and security are considered lower needs, while socialization, esteem, and self-actualization are considered higher needs. For Maslow, one must go through the hierarchy to achieve the higher or highest needs which means that lower needs must be satisfied first before working for higher or highest needs. However, Maslow's position was revised, if not rejected by other theorists such as Alderfer (1969) and others. It is considered a revision because the content theory of Maslow is still included in the discussion of other theories. For example, Hezberg, et.al. (1959), McClelland (1987) and Alderfer (1969). Herzberg's hygiene motivation theory (1959) or two-factor theory argued that people are motivated by the work itself, achievement and recognition. Work is seen as a responsibility and as a means for advancement and recognition which is still part of social needs, esteem, and self-actualization of Maslow. People are motivated to work to achieve the goals and by achieving the goals, people are recognized as long as the hygiene factor or the working environment is supportive. When the hygiene factor or working environment is not supportive, the spirit of people to work can be hampered. Therefore, a good working relationship, job security, and good salary are important factors maintain motivation. Interpersonal relationships, job security, working conditions, and salary are called hygiene factors of motivation. These factors must be healthy in order to motivate people to carry out their work. Further, Maslow's theory was revised further by McClelland in Mulder (2015) as he pointed out the three different sources of motivation such as the need for affiliation, need for power and needs for achievement. The need for affiliation is 
still part of Maslow's social needs. McClelland pointed out these three basic needs as common to human motivation. Each person has the motivation to be connected to other people and has the desire to gain the power to control and at the same time has the desire to achieve the goals. While Alderfer (1969) simplified Maslow theory into three categories of sources of motivation which is existence need, relatedness needs, and growth needs.

As explained by the content theory of motivation, motivation is also explained by the process theory of motivation which is presented by Vroom's expectancy theory, Adam's equity theory, goal-setting theory, and reinforcement theory. According to Vroom's expectancy theory, the reward is the primary motivation why a person exerts a certain level of effort to work because of the expectations that good performance will be rewarded. Vroom's expectancy theory is not just about self-interest reward but how the association people make toward the outcome and the contribution they make toward the outcome (Vroom, 1964 in Mulder, 2018). While equity theory argues that employees are motivated if they are treated according to their inputs and outputs. Employees will not consider fair treatment when there is a difference in inputs or outputs but treated the same. When the employees see such treatment, they will adjust their input to reach their perceived equity (Adam, 1965).

In contrary to the expectancy theory is the goal-setting theory which argues that not all people or employees are motivated by rewards or bonuses, but people are also motivated by challenging goals or challenging tasks. The theory argues that specific and challenging goals contribute to higher performance (Locke, 1996). Though this theory cannot be applied universally, this theory can be applied to people who have the ambition, capability, personality, knowledge, and skills because if they are not given the task that matches their personality, knowledge, skills, and capability, they might feel bored. Lastly is the reinforcement theory of motivation contends that the desired level of motivation can be achieved through reinforcement. It means that when someone performs a good job, he/she must be rewarded or praised to maintain the performance. Or if they perform a poor job, then the person must be punished so that he/she will not repeat the poor performance. The purpose of this approach is to establish the desired behavior in carrying out the task. This approach can be done positively or negatively (Ferster \& Skinner, 1957). Positive reinforcement can be done when the person performs a good job and negative reinforcement can be done when the behavior does not lead to good outcomes. Punishment is a signal not to repeat the behavior, while praise or reward is a signal that the behavior should be repeated.

Motivations, as explained by those theorists, are not only triggered by the unmet individual needs, be it physical or psychological needs but they are also triggered by social needs as pointed out by Maslow and this is what we call social motivation. The Free Dictionary defines social motivation as "a drive resulting from a social-cultural influence that initiates a behavior toward a particular goal". The social needs are influenced by culture, society, lifestyle and other external factors and these motivations are called extrinsic motivation (Deci, \& Ryan 2000). Extrinsic motivation would argue that people work, not only to achieve his/her needs for survival or existence but also to achieve social needs, such as recognition (Hezberg, 1959) from management and from other people in the workplace or from the society. This was pointed out by Maslow (1943), McClelland (1987) and Alderfer (1969) that some of the needs are social belongingness, affiliation, and relatedness. In other words, people have the need to be accepted by the group and by society. These needs motivate an individual person to behave in a certain way in order to be accepted by other people or groups. Social psychologists such as Forgas, Williams, and Laham (2005, p. 5, cited from Buss, (1999) recognize the importance of social motivation. They argue that social motivation is "a cornerstone of our remarkable evolutionary success as species". Our ability to connect to other people and work together with other people in a beneficial way is a defining character of human beings which are called Homo sapiens. They contended that our interactions, affiliation, and cooperation with other people are motivated by social motivations. Baumeister and Leary (1995) reemphasized that motivation such as the need to belong is fundamental to human sociability and gregariousness. Maintaining a healthy social contact or social affiliation is important for the maintenance of a healthy sense of adjustment and a sense of identity. It is not just psychological demands, but it is also cultural demands that motivate the individual person to establish linkages with other people in society. This is what Deci and Ryan (2000) extrinsic motivation.

\section{Organizational respect for the employee}

It cannot be denied that respect can boost the morale of employees to work for the organization. Thus, it should become organizational cultures to be continuously practiced by the management toward their employees and employees toward management. In philosophy and ethics, respect is considered a fundamental right of each human being. Kant (1993) argued that humans must be treated with dignity and this is the categorical imperative. It means that it is the duty of human beings to respect other human beings. Respect other people is not a choice but a must. Therefore, receiving and giving respect is understood to be a fundamental right and duty of human beings (Kant, 1993). Respect communicates the recognition of one's existence (Honneth, 1992), and encourages positive views of one's self to which all human beings are thought to be entitled (Rawls, 1971).

A respectful management style may be reflected in inclusive management in which the management embraces all employees' ideas in running an organization. One's voice is not left out. By inclusive and collaborative leadership and management, leaders or managers consider employees to be great contributors to the success of an organization and therefore employees are not left out in decision making. By applying such an inclusive management style, the management nurtures a collaborative environment. According to Potter, 2014), without respect for collaboration, a hierarchy will most likely be the dominating management approach. Inclusive and collaborative leadership implies respect for the leadership or management toward general or individual employees in the organization. Such inclusion makes the employees feel valued by the organization (Rogers \& Ashforth, 2014, pp. 1578-1608). In this 
case, the management or leadership has a deep regard for an individual employee. The employees feel worthy of his/herself because of the qualities and capabilities he/she brings to the organization (Heatfield, 2019, para. 1)

It has been also argued that an organization that has genuine respect for all employees remains competitive. Why so? Respect produces positive mental health or flourishing(Keyes, 2007). Positive mental health or flourishing is a subjective well- being which has three dimensions such as emotional, social and psychological (Westerhof \& Keyes, 2009). It contends that flourishing leads to effective functioning (Huppert \& So, 2013) which means that when people are happy, they can function well and lead to productivity and performance which produces competitiveness. Competitive organizations have similar critical components such as shared core values between management and all employees which is marked by respect. Living the value of respect within the organization will eventually gain employees' loyalty to the organization. Within such an environment, every employee considers respect as a significant work/ life issue that must be guarded. Further, a respectful environment can be seen in how management and employees treat all staff equitably and employees treat co-employees equitably, with dignity and politeness (Prince, 2000). In this kind of environment, employees serve as a valuable asset in establishing and enhancing the organizational prestige and when they see themselves as valuable assets, they feel attached to their employers and organization (Bartel, Wrzesniewski, \& Wiesenfeld, 2012). Being respected signals acceptance by management and others and it enhances the quality of relationships with the management and co-workers (Bartel et al., 2012; Blader \& Tyler, 2009).

\section{Employer Care}

Wekelo (2018), a Managing Director of HR and Operations at Actualize Consulting Firm, contended that showing empathy toward employees should be one of the management's responsibility. He maintains that creating an emphatical environment could become the strength of the organization. It gives a positive feeling or flourishing and usually, such positive well-being would lead to effective functioning (Huppert \& So, 2013). Wekelo (2018) further argues that when an employer treats their employees as human beings with feelings, dignity, not just workers, it makes a significant difference in the workplace. Based on her surveys, she argued that most employees wanted their managers to show empathy to their employees. Based on her study, she found that an emphatic workplace produces a positive impact on business performance.

Within the emphatic environment, management sees employees as partners in carrying out the vision and mission of the organization. Thus, in the first place, the management should show the employees the direction of the organization. In order to motivate employees to carry out the vision and mission, the management have to take care of employees particularly their social security and Medicare, insurance, paying the right wages/salary, maintaining safety standards, maintaining proper equipment and tools, creating harmonious working relationship, updating employees' skills and knowledge and empowering employees through management's effort to disseminate information about the organization to the employees (Durden, 2019). These are factors that contribute to the well-being of the workplace. In relation to these factors, Mercer (2019) has conducted a study which is reported in The Global Talent Report, 2018, and he found that there are three factors that employees and job candidates are looking for in a company and these are work flexibility, commitment to health and well-being and working with a purpose (Kohl, 2018). In terms of work flexibility, the report argues that five workdays are outdated and employees or around $51 \%$ of employees wanted flexible schedules. Besides work flexibility, commitment to the health and well-being of employees is to be important for the employees. The employees want that their employers care about their health, treatment as human beings and well-being which include physical, psychological and financial wellness. Lastly is working with a purpose. The study emphasizes that employees are not inspired when they do not see the direction and such a situation makes the employees difficult to connect their work with the company.

\section{The intrusion of work into private life}

It is a reality that nowadays office work does not have a boundary. It is supposed to be limited to the office of the company but, often time office work is extended to home. It is supposed to be family hours, but it is used for office work. Such a situation, besides other reasons, may happen because of the deadline given to the employees in which employees are required to finish certain work within a certain period but the employees cannot finish the work within the imposed deadline within the office (Shorr, 2017). It is common that such a deadline causes the employees stressed and pressured to meet the target and often time find it hard to "wind down" after work. Consequently, work is extended into the private zone of employees, it eats his/her private life. Such practice can impact negatively on employee's self -esteem and her well-being. It seems that the boundary of professional and personal life has become blurred, with no boundaries, no breaks (Salomon as cited by Dresdale, 2016). The study of Harvard Business School as cited by Rollings (2019) found that deadlines make people less creative and illicit stress and anxiety in the working world. The deadline contributes to "tunnel vision" in which the employees focus on the deadline ahead and forget another important task.

Some experts argue that work and personal life should not be a two-separate thing, but it should be integrated. They argue that this is the reality of the time. It is already considered unrealistic to separate a person's work life and personal life. According to them that what is important is work-life integration in the sense that the two worlds should co-exist. With the help of technology, personal life and professional life are integrated. Technology makes it possible that one can enjoy a vacation, family affairs without necessarily leaving one's work because he/she can open the emails and join the work conference from a distance (Dresdale, 2016). This implies that so long we can still contribute our time to the accomplishment of an organization's work from wherever you are in this world, 
one does not really need to be physically present in the office (Bonev, 2017). According to Burkus (2016) and Groysberg and Abrahams (2014) integrating the two functions may be a better strategy for enhancement of well-being and performance.

However, given the above arguments, some people still believe that there must be a separation between and work and one's private life. Stenger (2018) argued that although drawing a clear line between work and personal life is not simple but if one allows his/her work-related to spill over into one's personal life, one may find herself/himself spending as much time on office drama over private life, family life. She explains that protecting personal space and setting a clear boundary at work can benefit one's mental well-being, reduce stress and improve social dynamics (Stenger, 2018). It is still recognized that separating work life and personal life is to create a balance between work and family. Separating the two roles can improve efficiency and reduce stress on the part of employees (Career Center, n.d).

\section{Autonomy need}

Deci and Ryan (2000) in their Self-Determination Theory, as cited by Abun (2019) have identified three kinds of innate psychological needs of every human being and they are autonomy, relatedness, and competence. The finding of Deci and Ryan (2000) confirmed that the satisfaction of these three needs is important or essential for human optimal functioning and well-being. When the three needs are absent will result in demotivation and hamper the growth of an individual which may lead to frustration (Vansteenkiste and Ryan, 2013). Therefore, the focus of management is to see to it that these innate needs have to be supported or developed.

Autonomy is the situation in which the employees are given the freedom and can set their own schedules and allowed them to decide on their own work. It is considered as an essential psychological need to be developed because the employees may experience the volition and self-direction when they are given the freedom to control their own work (Legault, 2016). In other words, through autonomy, the company or the managers allow the employees to control their own work situation. Experts argued that when the employees are given those freedoms, the company can benefit from it. The company can flourish when the staff members have the freedom to approach their job in a way that suited their personalities and skills (Smith, 2019). Autonomy supportive environment can produce satisfied employees, and satisfied employees can contribute to the overall business success. It has been commonly agreed that when the employees are given the autonomy or freedom to do the job according to what and how they are going to accomplish it without the necessary intervention and monitoring from the management, the level of job satisfaction increases and the level of turnover decreases (Robertson, 2019).

\section{Competence need}

Competence is one of the innate psychological needs of a human being. It is innate because the human being is born with it and therefore a proper environment is needed for such need to grow. Competence need has been defined as individuals' inherent desire to feel effective in interacting with the environment (Deci \& Ryan, 2000; White, 1959). It has been stated that competence need allows the individual to explore the environment and engage in challenging task to test his/her ability and skills. The satisfaction of such need allows the individual to adapt to complex and changing environments, whereas competence frustration is likely to result in helplessness and a lack of motivation (Deci \& Ryan, 2000). Legault (2017) contends that the desire to satisfy the need for competence motivates people to persist, maintain efforts and self-determination to continue to improve one's skills and abilities. Satisfying competence need is essential for psychological growth and well-being.

Although such need is innate in nature, it needs a certain environment in order to grow. A supportive environment where they need can grow is needed particularly social and cultural environment. Such need may be hampered to grow in the environment where there is constant monitoring, supervision, criticism coming from management and peers. Under such an environment, competence needs may not develop. This has been pointed out by Deci (1971) in his study that giving people unexpected positive feedback on a task increases people's intrinsic motivation to do it, and therefore the feeling of competence is satisfied. On the contrary, Vallerand and Reid (1984) in their study found that negative feedback has the opposite effect. It decreases intrinsic motivation by discouraging people to develop their competence need. Criticism demotivates people to develop their competence and lead to a decrease in selfconfidence.

\section{Relatedness need}

Relatedness need is an inner desire to have "close harmonic relations" with another human being. In Psychology Dictionary, relatedness is defined as "reciprocity of factors like trust and empathy between two or more persons in a relationship". This need had been identified by Alderfer in his ERG theory as he argued that human being has three kinds of needs and they are existence needs, relatedness needs, and growth needs. Relatedness need is a social need in which human being has a need to be involved with family, friends, co-workers, and employers. According to Deci and Ryan (2000), relatedness need is one of the innate basic psychological needs of a human being. The individual person has such needs by nature, and he/she cannot live without it. Therefore, such need must be nurtured or developed in order for a human being to reach its optimal function. It is considered as an individual's inherent propensity to feel connected to others, to be a member of a group, to love and care, and to be loved and cared for (Baumeister \& Leary, 1995). This need can grow in an environment where people experience a sense of communion and where people can develop a close and intimate relationship with others (Deci \& Ryan, 2000). The concept of relatedness need is consistent with the theory of 
organizational psychology such as social support (Viswesvaran, Sanchez, \& Fisher, 1999) and loneliness at work (Wright, et.al.,2006).

Studies have proven that fulfilling such basic needs predicts well-being as pointed out by Patrick, et.al (2007). Their studies concluded that the satisfaction of relatedness needs correlate to the strong relationship among people and well-being. Thus Heartland, et.al (2011) recommended that management or leadership should provide a room where the three basic psychological needs are exercised and fulfilled. Such recommendation is even recommended earlier by Patrick, et.al (2007) that these three basic psychological needs must be supported in order to develop and consequently improve optimal functioning and optimal well-being of employees. Related to such recommendation, Reis, et.al (2000) had pointed out that daily well-being is the product of the fulfillment of autonomy. This argument was also presented by Chang, Huang, and Lin (2015) in their study that the fulfillment of the three basic psychological needs contributes to the well-being of employees.

\section{Work engagement}

The concept of work engagement seems to be easy at first glance but a closer look at different literature reveals different concepts or understanding about work engagement because the concept has evolved through the years and has different meanings. Those different meanings came out as a result of practice in the field (Schaufeli, 2013). The first person who conceptualized the work engagement was Kahn (1990). Kahn's work engagement means, "harnessing of organizational members' selves to their work roles; in engagement, people employ and express themselves physically, cognitively, and emotionally during role performances" (p. 694). It means that people are integrated into their work, there is no separation between personal selves and the work. Inspired by this definition, Rothbard (2001) conceptualized his own definition of work engagement as a two-dimensional construct to include attention in terms of time spent thinking about one's role at work and absorption in terms of intensity of one's focus on a role at work. Later Schaufeli, et.al (2002) somehow defined work engagement as Rothbard as "a positive, fulfilling, work-related state of mind that is characterized by vigor, dedication, and absorption" (p. 74). In this case, work engagement refers to three characteristics and they are vigor, dedication, and absorption. Vigor is characterized by high energy dedicated to the work, mental resilience while working and the willingness to invest effort in one's work" (p. 74). The dedication was characterized as "a sense of significance, enthusiasm, inspiration, pride, and challenge" (p. 74). And Absorption was characterized as "being fully concentrated and deeply engrossed in one's work, whereby time passes quickly, and one has difficulties with detaching oneself from work" (p. 75), and this concept is somehow related to the earlier concept of Kahn (1990). Harter, Schmidt, and Hayes (2002) understood work engagement as "the individual's involvement and satisfaction with as well as enthusiasm for work" (p. 269). In other words, work engagement is involvement as a result of satisfaction and enthusiasm over the work.

After reviewing the concept of work engagement, it looks like that money is not mentioned as part of the whole process of work engagement. It was argued that though at the beginning one may decide to join a certain company because of the salary, the brand name of the company and other benefits but it is not necessarily translating it into work engagement as understood by different experts that we have mentioned above but work engagement happens when the employee find meaning, autonomy, impact, and connection or MAGIC on what the employees do (DecisionWise Leadership Intelligence, n.d, cited by Abun, 2019). This argument was confirmed by the study conducted by Gallup report, a business journal that the majority of the global workforce is not engaged in their work, but disengagement was not caused by money, but employees do not find meaning and connection in their work. The report indicated that many workers are reluctant to heading to their work, lacking energy and passion in their job. This is the challenge of management on how to convince these employees to engage in their work in order to improve performance and attain sustainable long-term growth (Reilly, 2014, as cited by Abun, 2019). Many researches have found that disengaging employees can cause a lot to the organization but engaged employees can be more productive and good for the organization (Saks, 2006) and would not resign from the organization (Harter, Schmidt \& Hayes, 2002, Schuck, Reio \& Rocco, 2011) and can interact positively with customers (Chalofsky, 2010).

\section{Independent Variables}

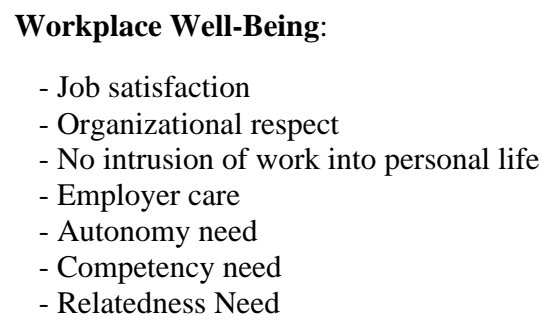

\section{Dependent Variable}

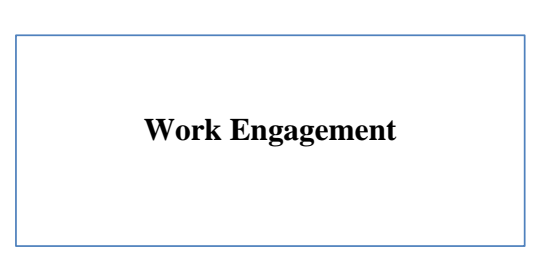

Fig.1: The framework illustrates the relationship between workplace well-being and work engagement. 


\section{Statement of the problems}

Based on the theories and conceptual framework of the study, the study would like to determine the relationship between workplace wellbeing and work engagement, specifically to answer the following questions:

What is the workplace well-being of employees in terms of:

Job satisfaction, Organizational respect, No Intrusion of work over personal life, Employer care, Autonomy needs, Relatedness needs Competence need

What is the work engagement of employees?

Is there a relationship between workplace well-being and work engagement?

\section{Assumption}

The study assumed that workplace well-being affects work engagement and it can be measured through statistical treatment. It is also assumed that the respondents answer the questions honestly.

\section{Hypothesis}

Schuck and Reio (2014) have already argued that workplace well-being affects work engagement. They argue that workforce engagement can be detrimental to the organization. Aiello, et.al (2018) also contend that there is a correlation between workplace well-being and work engagement. Based on their theory, the current study hypothesized that there is a correlation between workplace wellbeing and work engagement.

\section{Scope and delimitation of the study}

The study limited itself to measure workplace well-being along with job satisfaction, organizational respect, work intrusion, employer care, autonomy need, relatedness need and competency need and work engagement of employees of Divine Word Colleges in the Ilocos region.

\section{Research and Methodology}

The study was carried out through appropriate research methodologies such as research design, data gathering instruments, population, the locale of the study, data gathering procedures and statistical treatment of data.

\section{Research design}

The study is using a descriptive correlational research design. It measures the correlation between the levels of workplace well-being and works engagement of the employees. The nature of descriptive research is to describe what is found in the data collected through questionnaires and statistical treatment. It is also used to describe profiles, frequency distribution, describe characteristics of people, situation, phenomena or related variables. In short, it describes "what is" about the data (Ariola, 2006, cited by Abun, 2019).

In line with the current study, the descriptive correlational method was deployed. The study determines the level of workplace wellbeing and how it affects their work engagement. This was to determine what the dominant psychological well-being among employees was and what particular workplace well-being affects the work engagement of employees.

\section{The locale of the study}

The locale of the study was Divine Word Colleges in Ilocos Region which is composed of Divine Word College of Vigan. Divine Word College of Vigan is belonged to the Province of Ilocos Sur and located within the heritage city of Vigan. Divine Word College of Laoag is located in Laoag City, Ilocos Norte. Divine Word Colleges in Region I are run by the Congregation of the Divine Word Missionaries or known as Society of the Divine Word or in Latin, Societas Verbi Divini (SVD).

\section{Population}

The population of the study was composed of all employees, teaching and non-teaching, of Divine Word Colleges in the Ilocos region. Since the total numbers of employees are limited, and therefore total enumeration is the sampling design of the study.

\section{Data gathering instruments \& Procedures}

The study utilized questionnaires. The questionnaires are validated questionnaires and adapted from Black Dog Institute on Workplace Wellbeing and from Basic Psychological Need Satisfaction and Frustration Scale (Chen, et.al 2015) to assess the workplace wellbeing. While questionnaires on work engagement were adapted from Abun (2019).

In the process of data gathering, the researcher sent letters to the President of the Colleges, requesting them to allow the researcher to flow his questionnaires in the college. The researcher personally met the Presidents and employees and requested them to answer the questionnaires. 
The retrieval of questionnaires was arranged between the President's representative and the researcher with the help of employees and faculty of the college.

\section{Statistical Treatment of Data}

In consistence with the study as descriptive research, therefore descriptive statistics are used. The weighted mean is used to determine the level of workplace well-being and work engagement and the Pearson $r$ will be used to measure the correlation between workplace well-being and work engagement.

The following ranges of values with their descriptive interpretation will be used in Table 1

Table 1: Ranges of values

\begin{tabular}{lll}
\hline Statistical Range & Descriptive Interpretation & Overall Descriptive Rating \\
\hline $4.21-5.00$ & Strongly agree & Very High \\
\hline $3.41-4.20$ & Agree & High \\
\hline $2.61-3.40$ & Somewhat agree & Moderate \\
\hline $1.81-2.60$ & Disagree & Low/High \\
\hline $1.00-1.80$ & Strongly disagree & Very Low/Very High \\
\hline
\end{tabular}

\section{Empirical Data and Analysis}

The findings of the study are presented bellow and arranged according to the structure of the statement of the problem of the study. The study wanted to find out the correlation between workplace well-being and work engagement of employees, specifically to answer the following questions:

Problem 1: What is the workplace well-being of employees in terms of:

\section{Job satisfaction}

Table 2: Work satisfaction

\begin{tabular}{lcc}
\hline Work Satisfaction & Mean & DR \\
\hline My work is fulfilling & 4.06 & $\mathrm{~A}$ \\
\hline My daily activities are giving a sense of direction and meaning & 4.02 & $\mathrm{~A}$ \\
\hline My work brings a sense of satisfaction & 3.98 & $\mathrm{~A}$ \\
\hline My work increased sense of self-worth & 4.04 & $\mathrm{~A}$ \\
\hline My work made me feel that as a person, I am flourishing & 4.02 & $\mathrm{~A}$ \\
\hline I feel capable and effective in my works on a day - to- day basis & 4.06 & $\mathrm{~A}$ \\
\hline My work offer challenges to advance my skills & 4.16 & $\mathrm{~A}$ \\
\hline Composite Mean & $\mathbf{4 . 0 5}$ & $\mathbf{A}$ \\
\hline
\end{tabular}

Source: Chen, et.al, 2015

Table 3: Legend

\begin{tabular}{llc}
\hline 4.21-5.00 & Strongly agree & Very High \\
\hline 3.41- 4.20 & Agree & High \\
\hline $\mathbf{2 . 6 1}-3.40$ & somewhat agree & Moderate \\
\hline $\mathbf{1 . 8 1}-\mathbf{2 . 6 0}$ & Disagree & Low/High \\
\hline $\mathbf{1 . 0 0}-1.80$ & Strongly disagree & Very Low/Very High \\
\hline
\end{tabular}

In terms of work motivation, the data reveals that as a whole, the employees agree (4.05) that they are satisfied. Even when the items are taken singly, the employees agree that the work is fulfilling (4.06), the daily activities are giving a sense of direction and meaning (4.02), the work brings a sense of satisfaction (3.98), the work increases sense of self-worth (4.04), the work makes me feel that as a person, they are flourishing (4.02), they feel capable and effective in my works on a day - to- day basis (4.06), and the work offer challenges to advance my skills (4.16). 
Table 4: Organizational respect

\begin{tabular}{|c|c|c|}
\hline Organizational Respect & & \\
\hline In general terms, I trust the senior people in my organization & 3.93 & $\mathbf{A}$ \\
\hline I believe in the principles by which my employer operates & 3.72 & A \\
\hline I feel content with the way my employer treats its employees & 3.56 & A \\
\hline I feel that the employer respects staff & 3.74 & A \\
\hline 5. People at my work believe in the worth of the organization & 3.75 & A \\
\hline Composite Mean & 3.74 & $\mathbf{A}$ \\
\hline
\end{tabular}

Source: Chen, et.al. 2015

The same assessment related to organizational respect. As indicated on the table, it shows that as a whole, the organization has respect for the employees as indicated by its weighted mean of 3.74 which means that the employees agree that there is respect for the employees and the organization. Even if the questions are taken singly, it has the same assessment that the employees agree that employees have trust to their senior people in the organization (3.93), they believe in their employers by which they operate (3.72), they feel content with the way their employer treats them (3.56), the employers respect their staff (3.74) and employees believe in the worth of the organization (3.75).

Table 5: Employer care

\begin{tabular}{|c|c|c|}
\hline Employer Care & & \\
\hline At a difficult time, my boss is willing to lend an ear & 3.76 & A \\
\hline My boss is caring & 3.78 & A \\
\hline I feel that my boss is emphatic and understanding about my work concerns & 3.75 & A \\
\hline My boss treats me as I would like to be treated & 3.69 & A \\
\hline My boss shoulders some of my worries about work & 3.66 & A \\
\hline I feel my transactions with my boss are, in general, positive & 3.69 & A \\
\hline I believe that my employer cares about their staff's well-being & 3.66 & A \\
\hline Composite Mean & 3.71 & A \\
\hline
\end{tabular}

Source: Chen, et.al. 2015

Based on the data presented on the table, it appears that as a whole, the employers care for their employees as indicated by its composite mean of 3.71 which means agree. Even when taking them singly, the results indicate the same that employees agree that at difficult time, their bosses are willing to lend an ear (3.76), their bosses are caring (3.78), they feel that their bosses are emphatic and understanding about their work concerns (3.75), their bosses treat them as they want to be treated 93.69), their bosses shoulder some of their worries about their work (3.66), their transaction with their bosses are positive (3.69), and they believe that their employers care about their staff well-being (3.66).

Table 6: the intrusion of work into private life

\begin{tabular}{lcc}
\hline The intrusion of work into Private life & \\
\hline My work takes all my time including my private life & 3.36 & SWA \\
\hline I feel stressed in organizing my work time to meet demands & 3.21 & SWA \\
\hline I feel excessively pressured at work to meet targets & 3.18 & SWA \\
\hline After work, I find it hard to wind down & 3.14 & SWA \\
\hline I find myself thinking negatively about work outside office hours & 2.87 & SWA \\
\hline Composite Mean & 3.15 & SWA
\end{tabular}

Source: Chen, et.al. 2015

Looking into the tabulated data, it shows that as a whole, the employees somewhat agree (3.15) that their work enters into their private life. Even when the items are taken singly, it appears that the employees somewhat agree that their works take all their time 
including their private life (3.36), they feel stressed in organizing their work time to meet the demands (3.21), they feel excessively pressured at work to meet targets (3.18), they find it hard to wind down (3.14) and they find themselves thinking negatively about work outside office hours (2.87).

Table 7: Autonomy needs

\begin{tabular}{lcc}
\hline Autonomy Needs & \\
\hline 1. At work, I feel a sense of choice and freedom in the things I undertake & 3.49 & $\mathrm{~A}$ \\
\hline 2. I feel that my decisions on my job reflect what I really want & 3.59 & $\mathrm{~A}$ \\
\hline 3. I feel my choices on my job express who really, I am. & 3.74 & $\mathrm{~A}$ \\
\hline 4. I feel I have been doing what really interests me in my job & 3.77 & $\mathrm{~A}$ \\
\hline Composite Mean & 3.65 & $\mathrm{~A}$ \\
\hline
\end{tabular}

Source: Deci and Ryan, 2000.

Concerning the autonomy needs of employees, the data reveals that, as a whole, the employees agree to the assessment of their autonomy needs as indicated by its composite mean of 3.65 which means they agree. Taking them singly, it reveals that the employees agree that at work they feel a sense of choice and freedom in the things they undertake (3.49), they feel that their decision on their job reflects what they really want (3.59), they feel that their choices on their job express who really they are (3.74) and they feel that they have been doing what really interests them in their job (3.77).

Table 8: Relatedness needs

\begin{tabular}{lcc}
\hline Relatedness Needs & 3.68 & $\mathrm{~A}$ \\
\hline 1. I feel that the people I care at work about also care about me & 3.76 & $\mathrm{~A}$ \\
\hline 2. I feel connected with people who care for me at work \& for whom I care at work & 3.84 & $\mathrm{~A}$ \\
\hline 3. At work, I feel close and connected with other people who are important to me & 3.88 & $\mathrm{~A}$ \\
\hline 4. I experience a warm feeling with the people I spend time with at work & 3.79 & $\mathrm{~A}$ \\
\hline Composite mean &
\end{tabular}

Source: Deci and Ryan, 2000.

The same assessment related to their relatedness need. It appears that as a whole, the employees agree to a certain extent that their relatedness need is met as indicated by its composite mean of 3.79 which means agree. Even when they are taken singly, it shows that employees agree that they care one another (3.68), they feel connected with people who care for them at work and whom they care for at work (3.76), and they experience a warm feeling with the people they spend time with at work (3.88).

Table 9: Competence need

\section{Competence Need}

\begin{tabular}{lcc}
\hline 1. I feel confident that I can do things well on my job & $\mathbf{4 . 0 2}$ & $\mathbf{A}$ \\
\hline 2. At work, I feel capable of what I do & $\mathbf{4 . 0 2}$ & $\mathbf{A}$ \\
\hline 3. When I am at work, I feel competent to achieve my goals & $\mathbf{3 . 9 8}$ & $\mathbf{A}$ \\
\hline 4. In my job, I feel I can successfully complete a difficult task & $\mathbf{3 . 9 9}$ & $\mathbf{A}$ \\
\hline Composite Mean & $\mathbf{4 . 0 0}$ & $\mathbf{A}$
\end{tabular}

Source: Deci and Ryan, 2000.

Lastly, concerning competence need, as a whole, it shows that employees to some degree agree that their competence needs are met as pointed out by its composite mean of 4.00 which means that they agree. When taken them singly, it reveals that the employees agree that they feel confident that they can do their work well (4.02), they feel capable at what they do (4.02), they feel competent to achieve their goals (3.98) and they feel that can successfully complete the difficult task (3.99). 
Table 10: Workplace well-being

\begin{tabular}{rlll}
\hline 1. & Work Satisfaction & 4.05 & $\mathrm{~A}$ \\
\hline 2. & Organizational Respect & 3.74 & $\mathrm{~A}$ \\
\hline 3. & Employee care & 3.71 & $\mathrm{~A}$ \\
\hline 4. & Work intrusion into private life & 3.15 & SWA \\
\hline 5. & Autonomy Needs & 3.65 & $\mathrm{~A}$ \\
\hline 6. & Related Needs & 3.79 & $\mathrm{~A}$ \\
\hline 7. & Competence needs & 4.00 & $\mathrm{~A}$ \\
\hline Overall Mean & 3.73 & $\mathrm{~A}$
\end{tabular}

Source: Deci and Ryan, 2000.

In summary table, the data reveals that as a whole, the employees agree to a certain extent that work satisfaction (4.05), organizational respect (3.74), employee care (3.71), autonomy needs (3.65), relatedness needs (3.79), and competence needs are met or satisfied. It is also revealed that to a certain extent, employees somewhat agree that their work has interfered with their private life.

Problem 2: What is the work engagement of employees?

Table 11: Work engagement

\begin{tabular}{|c|c|c|}
\hline Work Engagement & Mean & DR \\
\hline I am willing to accept change & 4.29 & A \\
\hline I am willing to take on a new task as needed. & 4.20 & A \\
\hline I take the initiative to help other employees when the need arises. & 4.12 & A \\
\hline I keep going even when things get tough & 4.03 & A \\
\hline I adapt quickly to difficult situations & 3.82 & A \\
\hline When at work, I am completely focused on my job duties & 4.02 & A \\
\hline I pro-actively identify future challenges and opportunities & 3.86 & A \\
\hline I am determined to give my best effort at work each day & 4.18 & A \\
\hline I am often so involved in my work that the day goes by very quickly & 3.89 & A \\
\hline I get excited about going to work & 3.80 & A \\
\hline I feel completely involved in my work & 3.96 & A \\
\hline I am inspired to meet my goals at work. & 4.05 & A \\
\hline I understand the strategic goals of my organization. & 3.97 & A \\
\hline I see to it that I work to the best I can to meet the objective of my organization. & 4.07 & A \\
\hline I see to it that what I do is in line with the organization's objectives. & 4.02 & A \\
\hline I am proud to be part of the team & 4.05 & A \\
\hline My team inspire me to work hard every day & 3.91 & A \\
\hline My team is always helping me to complete my work & 3.90 & A \\
\hline I have good information about my work & 3.90 & A \\
\hline I have a good understanding of informal structures and processes at the organization & 3.80 & A \\
\hline Composite Mean & 3.99 & $\mathbf{A}$ \\
\hline
\end{tabular}

Source: Abun, 2019.

Looking into the data, it shows that as a whole, the employee agrees that they are engaging their work as indicated by its composite mean of 3.99 which is understood as agreeing. Even when the items are taken singly, it manifests that employees also agree in all questions, that they are willing to accept change (4.29), are willing to take on new tasks as needed (4.20), they take the initiative to help other employees when the need arises (4.12), they keep going even when things get tough (4.03), they adapt quickly to difficult 
situations (3.82), they are completely focusing on their job duties (4.02), they pro-actively identify future challenges and opportunities (3.86), they are determined to give their best effort at work each day (4.18), they are often so involved in their work that the day goes by very quickly (3.89), they get excited about going to work (3.80), they feel completely involved in their work (3.96), they are inspired to meet their goals at work (4.05), they understand the strategic goals of their organization (3.97), they see to it that they work to the best they can to meet the objective of their organization (4.07), they see to it that what they do is in line with the organization's objectives(4.02), they are proud to be part of the team (4.05), the team inspires them to work hard every day (3.91), the team is always helping one another to complete their work (3.90), they have good information about their work (3.90) and they have good understanding of informal structures and processes at the organization (3.80).

Problem 3: Is there a relationship between workplace well-being and work engagement?

Table 12: Workplace well-being and workplace engagement

\begin{tabular}{llll}
\hline & & Workplace Well Being & $\begin{array}{l}\text { Workplace } \\
\text { Engagement }\end{array}$ \\
\hline Workplace Well Being & Pearson Correlation & 1 & $.370^{* *}$ \\
\cline { 2 - 4 } & Sig. (2-tailed) & 170 & .000 \\
\cline { 2 - 4 } & $\mathrm{N}$ & $.370 * *$ & 170 \\
\hline Workplace Engagement & Pearson Correlation & .000 & 1 \\
\cline { 2 - 4 } & Sig. (2-tailed) & 170 & 170 \\
\cline { 2 - 3 } & $\mathrm{N}$ & & \\
\hline **. Correlation is significant at the 0.01 level (2-tailed). &
\end{tabular}
Source: Chen, 2015, Abun, 2019.

As it is indicated in the Pearson $r$ correlation, it reveals that there is a significant correlation at the 0.01 level (2-tailed) between workplace well-being and work engagement of employees. In other words, workplace well-being correlates significantly to work engagement.

\section{Result and Discussion}

The study was to determine the correlation between the workplace well-being and work engagement of employees. The result of the study shows that workplace well-being such as work satisfaction, organizational respect for employees, employer care, the intrusion of work into private life, autonomy needs, relatedness need, and competence need correlate with work engagement. It means that improving workplace well-being is a crucial factor for improving the work engagement of employees. Failing to give importance to the elements of workplace well-being will result to disengaged employees. Disengaged employees result to lower productivity and high cost.

The results of this study suggest that school administrators should give more importance to improving workplace well-being. Failing to give importance to the concern of employees in relation to their needs will jeopardize the quality of education. Quality education is a product of a happy workforce and thus, management needs to care for its employees because they are the company's assets.

\section{Conclusions}

The result of the study supports the hypothesis which was based on the finding of Schuck, et.al (2011) that workplace well-being is detrimental to the work engagement of employees. This study proves that both variables, workplace well-being, and work engagement are correlated. Solving work problems and employees' problems means that the management or the administrators of the school should look into their well-being.

The author recognizes that the variables of the study are limited to the seven variables and the author believes that there are other variables such as cognitive, emotional, and behavioral energy employees direct toward their work that can affect the work engagement of employees. Therefore, the future study needs to be expanded to include the attitude of employees toward and work engagement.

\section{References}

Abun, D. (2019). Measuring Basic Psychological Need Satisfaction and Frustration and Work Engagement of Employees of Divine Word Colleges in Ilocos Region, Philippines. International Journal of English Literature and Social Sciences (IJELS), 4(2), April 2019. https://dx.doi.org/10.22161/ijels.4.2.21

Adam, J.S. (1965). Inequality in social exchange. Advanced Experimental Psychology. 62, 335-343.

Aiello, A. Tesi, A. \& Gianetti, A. (2018). The work-related well-being of social workers: Framing job demands, psychological wellbeing, and work engagement. Journal of Social Work, 19(1), 121-141

Alderfer, C. P. (1969). An empirical test of a new theory of human needs. Organizational Behavior and Human Performance. 4 (2): 142-75. DOI:10.1016/0030-5073(69)90004-X.

Ariola, M.M. (2006). Principles and Methods of Research. Manila: Rex Book Store. 
Bartel, C. A., Wrzesniewski, A., \& Wiesenfeld, B. M. (2012). Knowing where you stand: Physical isolation, perceived respect, and organizational identification among virtual employees. Organization Science, 23 (3), 743-757. DOI:10.1287/orsc.1110.0661

Baumeister, R., \& Leary, M. (1995). The need to belong. The desire for interpersonal attachments as a fundamental human motivation. Psychological Bulletin, 117(3), 497-529.

Blader, S. L., \& Tyler, T. R. (2009). Testing and extending the group engagement model: Linkages between social identity, procedural justice, economic outcomes, and extra-role behavior. Journal of Applied Psychology, 94(2), 445-464. DOI: $10.1037 / \mathrm{a} 0013935$

Black Dog Institute (n.d). Workplace Well-Being. Retrieved from https://blackdoginstitute.org.au/docs/defaultsource/factsheets/workplacewellbeing.pdf

Bonev, A. (2017). Work-Life Balance vs. Work-Life Integration: What is the difference? JC Lookingglass. Retrieved from https://medium.com/the-looking-glass/work-life-balance-vs-work-life-integration-e92ebc32e6c5

Shuck, B. \& Rejo, Th. G. (2014). Employee Engagement and well-being. Journal of Leadership \& Organizational Studies, 2014, 21(1) 43-58

Burkus, D. (2016). Research: Keeping Work and Life separate is More Trouble Than It Is Worth. Harvard Business Review. Retrieved from https://hbr.org/2016/08/research-keeping-work-and-life-separate-is-more-trouble-than-its-worth

Buss, D. M. (1999). Human nature and individual differences: The evolution of human personality. In L. A. Pervin and O. P. John (Eds.), Handbook of Personality: Theory and Research (2nd ed., pp. 31-56). New York: Guilford Press.

Career Center. (n.d). Separate Your Personal and Professional Life. UCCS: University of Colorado, Colorado Springs. Retrieved from https://www.uccs.edu/career/resources/students/professional-etiquette-in-the-workplace/separate-your-personal-andprofessional-life

Chalofsky, N. E. (2010). Meaningful workplaces: Reframing how and where we work. New Jersey, NJ: Wiley

Chang, J.H., Huang, C.L. \& Lin, Y.C. Mindfullness, Basic Psychological Need Fulfillment and Well-Being. Journal of Happiness Studies, 16(5), 1149-1162 (2015).

Chen,B., Vansteenkiste, M., Beyers, W., Boone, L., Deci, E.L., Kaap-Deeder, J.V., Duriez, B., Lens, W., Matos,L., Mouratidis,A., Ryan, R.M., Sheldon, K.M., Soenens,B., Petegem, S.V., \& Verstuyf, J. (2015). Basic psychological need satisfaction, need frustration, and need strength across four cultures

Chang, J.H., Huang, Ch.L., \& Lin, Y.C. (2015). Mindfulness, Basic Psychological Needs Fulfillment and Well-Being. Journal of Happiness Studies, 16(5), 1149-1162.

Davis, T. (2019). What is Well-Being? Definition, Type and Well-Being Skills. Psychology Today. Retrieved from https://www.psychologytoday.com/us/blog/click-here-happiness/201901/what-is-well-being-definition-types-and-wellbeing-skills

deCharms, R. (1968). Personal Causation. New York: Academic Press

Decision Wise Leadership Intelligence (n.d). Employee Engagement Survey. Retrieved from www.Decision-Wise.com

Deci, E. L. (1971). Effects of externally mediated rewards on intrinsic motivation. Journal of Personality and Social Psychology, 18(1), 105-115.

Deci, E. L. \& Ryan, R.M. (2000). "Intrinsic and Extrinsic Motivations: Classic Definitions and New Directions". Contemporary Educational Psychology. 25(1): 54 67. CiteSeerX 10.1.1.318.808. DOI:10.1006/ceps.1999.1020

Dresdale, R. (2016). Work-Life Balance vs. Work-Life Integration, Is there really a difference? Forbes. Retrieved from https://www.forbes.com/sites/rachelritlop/2016/12/18/work-life-balance-vs-work-life-integration-is-there-really-adifference/\#5686f6e 23727

Durden, O. (2019). What Responsibilities Does Business Have towards Its Employees? Chron. Retrieved from https://smallbusiness.chron.com/responsibilities-business-toward-its-employees-25364.html

Ferster, C. B., \& Skinner, B. F. (1957). Schedules of reinforcement. Retrieved March 27, 2019, from https://psycnet.apa.org/PsycBOOKS/toc/10627

Forgas, J.P., Williams, K.D., \& Laham, S.M.( Ed.). (2005). Social Motivation; Conscious and Unconscious Process. UK: Cambridge University Press

Groysberg, B. \& Abrahams, R. (2014). Manage Your Work and Manage Your Life. Harvard Business Review. Retrieved from https://hbr.org/2014/03/manage-your-work-manage-your-life

Harter, J., Schmidt, F. L., \& Hayes, T. L. (2002). Business-unit-level relationship between employee satisfaction, employee engagement, and business outcomes: A meta-analysis. The Journal of Applied Psychology, 87(2), 268-279. DOI: $10.1037 / 0021-9010.87 .2 .268$

Harter, S. (1978). Effecting motivation is reconsidered: toward a developmental model. Human Development, 21(1),661-669.

Heatfield, S.M. (2019). How to Demonstrate Respect in the Workplace. Retrieved from https://www.thebalancecareers.com/howto-demonstrate-respect-in-the-workplace-1919376

Heartland, H., Hetland, J., Andreassen, C. S., Pallesen, S., \& Notelaers, G. (2011) "Leadership and fulfillment of the three basic psychological needs at work", Career Development International, 16(5), 507523, https://doi.org/10.1108/13620431111168903

Herzberg, F., Mausner, B., \& Snyderman, B. B. (1959). The Motivation to Work (2nd Ed.). New York: John Wiley. ISBN 0471373893 
Honneth, A. (1992). Integrity and disrespect: Principles of a conception of morality based on the theory of recognition. Political Theory, 20(2), 187-201

Huppert, F. A., \& So, T. T. C. (2013). Flourishing across Europe: Application of a new conceptual framework for defining wellbeing. Social Indicators Research, 110(3), 837-861. Doi:10.1007/s11205-011-9966-7

Kahn, W. A. (1990). Psychological conditions of personal engagement and disengagement at work. Academy of Management Journal, 33(4), 692-724. DOI:10.2307/256287

Kant, I. (1993). Grounding for the metaphysics of morals. Indianapolis, IN Hackett.

Keyes, C. L. M. (2007). Promoting and protecting mental health as flourishing: A complementary strategy for improving national mental health. American Psychologist, 62(2), 95-108. DOI:10.1037/0003- 066X.62.2.95

Kohl, A. (2018). What Employees Really Want at Work? Forbes. Retrieved from https://www.forbes.com/sites/alankohll/2018/07/10/what-employees-really-want-at-work/\#3e11512f5ad3

Legault, L. (2016). The Need for Autonomy. New York: Springer International Publishing.

Legault, L. (2017). The Need for Competence. New York: Springer International Publishing.

Locke, E. A. (1996). "Motivation through conscious goal setting". Applied and Preventive Psychology. 5(2): 117-124. DOI:10.1016/S0962-1849(96)80005-9.

Maslow, A.H. (1943). A Theory of Human Motivation. Psychological Review, Vol. 50, Issue 4, 370-96. Retrieved from https://psycnet.apa.org/record/1943-03751-001

McClelland, D.C. (1987). Human motivation. New York: University of Cambridge.

Mercer (2019). $\quad$ Global Talent $\quad$ Trend, 2019. $\quad$ Retrieved from https://www.mercer.com/content/dam/mercer/attachments/global/Career/gl-2019-global-talent-trends-study.pdf

Mulder, P. (2015). McClelland Motivation Theory. Retrieved, March 29, 2019, from Tools Hero: https//www.toolshero.com/psychology/theories of motivation/McClelland-motivation-theory/

Mulder, P. (2018). Vroom's Expectancy Theory. Retrieved, March 29, 2019, from Tools Hero: https//www.toolshero.com/psychology/theories-of - motivation/vrooms-expectancy - theory/

Patrick, H., Knee, C. R., Canevello, A., \& Lonsbary, C. (2007). The role of need fulfillment in relationship functioning and wellbeing: A self-determination theory perspective. Journal of Personality and Social Psychology, 92(3), 434-457. http://dx.doi.org/10.1037/0022-3514.92.3.434

Potter, T. (2014). Breaking down the hierarchies. Nursing Management - UK, 21(5), and 12.

Prince, M. (2000). Respect for employees seen as key to retention. Business Insurance, 34(16), 16.

Rawls, J. (1971). A theory of justice. Cambridge, MA: Harvard University Press.

Reilly, A. (2014). Whatever Engaged Employees do such as Solve Problems. Course Hero. Retrieved from https://www.coursehero.com

Reis, H. T., Sheldon, K. M., Gable, S. L., Roscoe, J., \& Ryan, R. M. (2000). Daily Well-Being: The Role of Autonomy, Competence, and Relatedness. Personality and Social Psychology Bulletin, 26(4), 419-435. https://doi.org/10.1177/0146167200266002.

Robertson, t. (2019). The Effect of Autonomy on Job satisfaction. Chron. Retrieved from https://work.chron.com/effects-autonomyjob-satisfaction-14677.html

Rogers, K.M. \& Ashforth, B.E. (2014). Respect in Organizations: Feeling Valued as "We" and "Me". SAGE journals, 43(5), page(s): 1578-1608.https://doi.org/10.1177/0149206314557159

Rollings, M. (2019). Do Deadlines Help Us Get Stuff Done? Hive. Retrieved from https://hive.com

Rothbard, N.P. (2001). Enriching or Depleting? The Dynamics of Engagement in Work and Family Roles. Administrative Science Quarterly, 46(4), 655-684

Saks, A. M. (2006). Antecedents and consequences of employee engagement. Journal of Managerial Psychology, 21(7), 600-619. DOI: $10.1108 / 02683940610690169$

Schaufeli, W.B. (2013). What is engagement? In C. Truss, K. Alfes, R. Delbridge, A. Shantz, \& E. Soane (Eds.), Employee Engagement in Theory and Practice. London: Routledge.

Schaufeli, W. B., Salanova, M., González-Romá, V., \& Bakker, A. B. (2002). The measurement of engagement and burnout: A two sample confirmatory factor analytic approach. Journal of Happiness Studies, 3(1), 71-92. DOI:10.1023/A:1015630930326

Shorr, B. (2017). Is Deadline Management Killing Your Company? Forbes. Retrieved from https://www.forbes.com/sites/allbusiness/2017/07/18/is-bad-deadline-management-killing-your-company/\#15790e753de4

Shuck, B., Reio, T. G., Jr., \& Rocco, T. (2011). Employee engagement: An examination of antecedent and outcome variables. Human Resource Development International, 14(4), 427-445. DOI:10.1080/13678868.2011.601587

Shuck, B., \& Reio, Th. G. (2014). Employee Engagement and Well-Being: A Moderation Model and Implications for Practice. Journal of Leadership \& Organizational Studies 2014, 21(1), 43-58

Smith, E. (2019). What is Employee Autonomy? Chron. Retrieved from https://smallbusiness.chron.com/employee-autonomy20930.html

Stenger, M. (2018). Four Ways to Keep Your Personal Life Out of the Office. Career Contessa. Retrieved from https://www.careercontessa.com/advice/privacy-work-life-balance/

Vallerand, R.J. \& Reid, G. (1984). "On the causal effects of perceived competence on intrinsic motivation: A test of cognitive evaluation theory". Journal of Sport Psychology. 6(1), 94-102. 
Vansteenkiste, M., \& Ryan, R. M. (2013). On psychological growth and vulnerability: Basic psychological need satisfaction and need frustration as a unifying principle. Journal of Psychotherapy Integration, 23(3), 263-280.

Viswesvaran, C., Sanchez, J. I., \& Fisher, J. (1999). The role of social support in the process of work stress: A meta-analysis. Journal of Vocational Behaviour, 54(2), 314-334.

Vroom, V. H. (1964). Work and motivation. Oxford, England: Willey.

Wekelo, K.A. (2018). 4 Ways Employers Should Show Their Employees They Care. Entrepreneur: Small Business Heroes. Retrieved from https://www.entrepreneur.com/article/312721

Westerhof G.J \& Keyes, C.L.M. (2009). Mental Illness and Mental Health: The Two Continua Model Across the Lifespan. Journal of Adult Development, 17(2), 110-119. DOI: 10.1007/s10804-009-9082-y

White, R. (1959). Motivation reconsidered: The concept of competence. Psychological Review, 66, 279-333

Wright, S. L., Burt, C. D., \& Strongman, K. T. (2006). Loneliness in the workplace: Construct definition and scale development. New Zealand Journal of Psychology, 35(2), 59-68. 